\title{
TUNGGU TUBANG DALAM PEMBAGIAN HARTA WARISAN PADA MASYARAKAT SUKU SEMENDE
}

\author{
Azelia Velinda, Wilodati, Aceng Kosasih \\ Universitas Pendidikan Indonesia \\ Jl. Dr.Setiabudi 229 Bandung 40154, Jawa Barat, Indonesia \\ Email: Azelia.velinda@student.upi.edu
}

\begin{abstract}
Abstrak Penelitian ini dilatarbelakangi oleh cara pembagian harta warisan pada masyarakat Suku Semende yang cukup unik dan berbeda dengan wilayah lainnya, sistem ini disebut dengan Tunggu Tubang. Penelitian ini dilakukan di Desa Gunung Agung Kecamatan Semende Darat Tengah Kabupaten Muara Enim Provinsi Sumatra Selatan. Jenis penelitian ini adalah penelitian kualitatif dengan metode studi deskriptif. Teknik pengumpulan data dilakukan dengan observasi, wawancara mendalam, studi dokumentasi, dan studi literatur. Temuan hasil penelitian ini adalah proses pembagian harta warisan di Desa Gunung Agung dilakukan dengan sistem Tunggu Tubang dimana anak perempuan yang terlahir pertama yang mendapatkan harta pusaka, harta pusaka ini berupa sebuah rumah dan sebidang sawah. Harta pusaka tidak dapat dijual dan hanya dapat menikmati hasil. Tugas Tunggu Tubang adalah menghimpun keluarga besar, mewakili keluarga besar, mengurus harta pusaka.

Kata kunci: tunggu tubang, pembagian harta waris, masyarakat suku semende
\end{abstract}

\section{PENDAHULUAN}

Keberagaman adat istiadat dan panutan hidup yang terdapat pada masyarakat Indonesia dilatarbelakangi oleh lokasi geografis negara Indonesia yang strategis sehingga menyebabkan daerah Indonesia menjadi daerah yang dilalui dalam perdagangan dunia, kondisi negara kepulauan sehingga menyebabkan masyarakatnya menjadi tepisah-pisah, selain itu perbedaan kondisi alam juga sangat memungkinkan timbulnya berbagai macam kebudayaan.

Masyarakat adat Indonesia mempunyai hukum adat waris masing-masing. Biasanya hukum adat mereka dipengaruhi oleh sistem kekeluargaan dan sistem perkawinan yang mereka anut. Hukum waris yang berlaku di kalangan masyarakat Indonesia sampai sekarang masih bersifat pluralistis, yaitu ada yang tunduk kepada hukum waris perdata, hukum waris islam dan hukum waris adat. Masyarakat Indonesia yang terdiri atas beragam suku bangsa memiliki adat istiadat dan hukum adat yang beragam antara yang satu dengan yang lainnya berbeda dan memiliki karakteristik tersendiri yang menjadikan hukum adat termasuk di dalamnya hukum waris menjadi pluralistis pula.

Hukum waris suatu golongan masyarakat sangat dipengaruhi oleh bentuk kekerabatan dari masyarakat itu sendiri, setiap kekerabatan atau kekeluargaan memiliki sistem hukum waris sendiri.
Sistem kekerabatan ini berpengaruh dan sekaligus membedakan masalah hukum kewarisan, disamping itu juga antara sistem kekerabatan yang satu dengan yang lain dalam hal perkawinan.

Suku Semende adalah suku yang berasal dari Kecamatan Semende, Kabupaten Muara Enim, Sumatra Selatan. Berbagai macam adat istiadat di suku ini masih terus terjaga sampai saat ini antara lain adat pernikahan, adat pewarisan dan kekerabatannya. Seperti yang telah diuraikan di atas ketiga hal ini sangatlah berkaitan dalam hukum adat yang terdapat di Suku Semende ini.

Sistem pewarisan pada masyarakat adat Suku Semende ini terbilang cukup unik. Dalam suku ini terdapat istilah Tunggu Tubang, yang merupakan status yang dipercayakan kepada anak perempuan tertua dalam suatu keluarga, dimana status tersebut adalah merupakan status otomatis yang sifatnya turun temurun dan biasanya status tersebut diterima setelah anak perempuan tertua menginjak menikah.

Tunggu Tubang sangatlah berkaitan dengan sistem pewarisan yang diterapkan pada masyarakat Suku Semende. Proses pewarisan dalam adat Semende menarik garis keturunan dari ibu yang sering disebut matrilineal. Dimana yang berhak menerima dan menjaga harta warisan adalah anak perempuan yang terlahir pertama yang dalam suku ini disebut sebagai Tunggu Tubang.

Pembagian harta warisan menurut adat Semende lebih mengutamakan perempuan dan bisa dikatakan apabila orang tua mereka sudah meninggal maka 
otomatis semua harta akan diberikan kepada anak tertua perempuan. Walaupun semua harta jatuh kepada anak perempuan, bukan berarti harta tersebut diperbolehkan untuk diperjual belikan. Saat ini pihak bank tidak mau menerima sertifikat rumah pada rumah-rumah di desa yang ada di kecamatan Semende karena telah mengetahui bahwa rumah disana tidak dapat diperjual belikan.

Maka Tunggu Tubang dalam masyarakat Suku Semende merupakan ujung tombak bagi keberlangsungan kehidupan di dalam masyarakat. Untuk itu dalam pembahasan yang akan dipaparkan bagaimana Tunggu Tubang dalam sistem pembagian harta warisan dalam masyarakat Suku Semende khususnya di Desa Gunung Agung Kecamatan Semende Darat Tengah Kabupaten Muara Enim Provinsi Sumatra Selatan.

\section{STUDI LITERATUR}

Hukum waris adat di Indonesia sangat dipengaruhi oleh prinsip garis keturunan yang berlaku di masyarakat yang bersangkutan. Menurut Muhammad (2013, hlm.10) secara teoritis keturunan dapat dibedakan menjadi 3 yakni: "Patrilineal, Matrilineal,dan Bilateral". Menurut Hadikusuma (1991, hlm.34) ketentuan Hukum Adat secara garis besar dapat dikatakan bahwa "sistem hukum waris Adat terdiri dari tiga sistem kewarisan Individual, kewarisan Kolektif, dan kewarisan Mayorat".

Hukum waris dengan sistem Tunggu Tubang berlaku pada masyarakat Suku Semende. Menurut Fakhri (2001, hlm.21) Tunggu Tubang juga memliki makna "nama jabatan yang dipercayakan kepada anak perempuan tertua dalam suatu keluarga, dimana jabatan tersebut adalah merupakan jabatan otomatis yang sifatnya turun temurun dan biasanya jabatan tersebut diadakan penyerahan setelah anak perempuan tertua menginjak berumah tangga", namun dalam hal ini orang tua dari anak Tunggu Tubang tersebut masih tinggal bersama-sama dengan anak Tunggu Tubang sampai anak tersebut dapat hidup mandiri dalam keluarga sebagaimana layaknya anak-anak Tunggu Tubang yang lainnya hidup dalam masyarakat.

Selanjutnya Tim peneliti adat (dalam Hutapea dan Thamrin , 2009, hlm.3) meyatakan "Kekuasaan laki-laki akan tetap dihormati". Yang membelanya adalah Meraje, Jenang Jurai, Puyang Jurai, dan Lebu Meraje/Jurai. Meraje adalah pemimpin terhadap Tunggu Tubang. Berapapun jumlahnya, hanya saja sewaktu berbicara yang tertua didahulukan. Sebagai orang yang bertugas mengawasi Tunggu Tubang,
Meraje diisyaratkan memiliki sifat yang baik dan suri tauladan bagi anak belai yang diawasinya, yaitu: adil, mengayomi, sabar, berwibawa dan tegas, cerdas dan tanggap mengatasi masalah, dan bijaksana mengatasi permasalahan dan mengambil keputusan.

Haryanto (2012) mengatakan "fokus teori ini adalah aspek struktural dari masyarakat dan prasyarat-prasyarat fungsional dari sistem sosial untuk memelihara keberlangsungannya. Oleh karena itu, inti teori ini dinamakan struktural fungsional, yang kemudian dirumuskan secara lebih sederhana menjadi fungsionalisme".

\section{METODE PENELITIAN}

Penelitian ini merupakan penelitian kualitatif dengan menggunakan metode studi deskriptik analitik. Penelitian dilakukan di Desa Gunung Agung Kecamatan Semende Darat Tengah Kabupaten Muara Enim Provinsi Sumatra Selatan.. Informan penelitian sebanyak 8 orang, terdiri atas enam orang informan kunci, dan dua orang informan pendukung. Partisipan dalam penelitian ini mencakup pemangku adat Suku Semende, kepala desa, dan masyarakat yang bestatus sebagai Tunggu Tubang dan yang berstatus bukan sebagai Tunggu Tubang. Pihak-pihak tersebut dianggap mempunyai informasi yang dibutuhkan peneliti untuk mengungkapkan permasalahan yang telah dirumuskan.Pemilihan partisipan untuk penelitian ini menggunakan purpossive sampling dan incidental sampling.Hasil penelitian yang diperoleh melalui teknik observasi, wawancara dan studi dokumentasi.

\section{HASIL DAN PEMBAHASAN}

Tunggu Tubang adalah sebuah status yang diberikan kepada anak perempuan yang terlahir pertama dalam sebuah keluarga. Menurut faris (2001, hlm. 21) "Tunggu Tubang adalah nama jabatan yang dipercayakan kepada anak perempuan tertua dalam sebuah keluarga dimana jabatan tersebut adalah jabatan otomatis yang sifatnya turun termurun dan biasanya penyerahan jabatan ini dilakukan setelah anak perempuan tertua menginjak berumah tangga". Jadi masyarakat suku ini menggunakan sistem matrilineal dalam sistem kekerabatannya karena perempuan menjadi hal utama dalam kehidupan.

Dalam pembagian harta warisan Tunggu Tubang berhak sepenuhnya atas semua harta yang diwariskan oleh leluhur keluarga mereka. 
Masyarakat suku Semende ini menganut sistem kewarisan mayorat perempuan, menurut Hadikusuma (1991) sistem kewarisan mayorat perempuan adalah anak perempuan tertua diberikan kuasa untuk menggantikan orang tua dalam penguasaan harta. Apablila dalam keluarga Tunggu Tubang tidak memiliki anak perempuan maka istri dari anak laki-laki pertama yang akan diberikan status sebagai Tunggu Tubang dan harus melalui ritual ngangkit anak terlebih dahulu hal ini untuk menandakan bahwa menantunya tersebut telah dijadikan anak oleh keluarga Tunggu Tubang dan setelah ritual maka harus menjalankan hak dan kewajiban sebagai seorang Tunggu Tubang.

Terdapat pula keluarga Tunggu Tubang yang tidak memilki anak maka status sebagai Tunggu Tubang akan diberikan kepada keponakan perempuan Tunggu Tubang yang berasal dari adik atau kakak perempuan Tunggu Tubang. Ada pula Tunggu Tubang yang tidak sanggup untuk menjalankan kewajibannya maka dilakukan musyawarah keluarga untuk menunjuk siapa yang bersedia mengganttikan posisi tersebut.

Harta warisan yang diterima oleh Tunggu Tubang adalah sebuah rumah dan sebidang sawah, hal ini memiliki makna antara lain sebuah rumah di desa dijadikan sebagai tempat berkumpul keluarga besar walaupun keluarga sudah pergi dari desa untuk merantau mereka tetap memiliki rumah di desa untuk pulang selanjutnya sebidang sawah adalah untuk menjamu keluarga besar yang sedang pulang ke desa. Kekerabatan masyarakat Suku Semende di Desa Gunung Agung sangat dekat ini merupakan dampak dari sistem Tunggu Tubang. Harta warisan tidak dapat diperjualbelikan Tunggu Tubang hanya berhak untuk menikmati hasil dari harta pusaka tersebut.

Tunggu Tubang juga memiliki kewajiban yang harus dijalankan disamping mendapatkan harta warisan yang merupakan hak sebagai Tunggu Tubang. Kewajiban seorang Tunggu Tubang adalah menjaga dan mengurus harta pusaka, menjaga dan mengurus orang tua, menghormati Meraje dan mematuhi perintahnya, serta mematuhi dan menjalankan aturan adat.

Meraje adalah saudara laki-laki dari ibu Tungu Tubang yang bertugas untuk mengawasi Tunggu Tubang. Tim peneliti adat (dalam Hutapea dan Thamrin 2009, hlm.3) menyatakan "kekusaan lakilaki akan tetap dihormati”. Maka dalam menjalankan kewajibannya Tunggu Tubang di awasi oleh Meraje apabila Tunggu Tubang melakukan kesalahan maka Meraje berkewajiban untuk menegur bahkan bila kesalahannya sudah fatal maka Meraje dapat mengambil alih harta pusaka.
Tunggu Tubang mempunyai larangan-larangan yang harus di jauhi, larangan tersebut antara lain adalah sebagai berikut :

a. Menolak keluarga yang datang kerumahnya.

b. Berperilaku kasar terhadap keluarga.

c. Menjual harta keluarga/ harta tubang.

d. Menggadaikan harta keluarga/harta tubang tanpa meminta izin dan pertimbangan dari jenang jurai (musyawarah keluarga).

e. Menelantarkan saudara-saudaranya sekandung yang belum berkeluarga yang berada dibawah asuhannya sebagai pengganti orang tua.

f. Membuka rahasia keluarga.

Dari pemaparan di atas diketahui bahwa menjadi seorang Tunggu Tubang sangatlah berat maka sejalan dengan pendapat yang mengatakan bahwa terdapat anak yang menolak statusnya sebagai Tunggu Tubang.

Sistem Tunggu Tubang ini harus terus dipertahankan agar tercipta keteraturan di dalam kehidupan masyarakat, Saifudin (2006, hlm.64) mengatakan bahwa "struktur fungsionalisme berasumsi tentang komponen-komponen sistem sosial, seperti halnya bagian-bagian tubuh suatu organisme, berfungsi memelihara integritas dan dan stabilitas keseluruhan sistem". Selanjutnya Haryanto (2012) mengatakan "fokus teori ini adalah aspek struktural dari masyarakat dan prasyarat-prasyarat fungsional dari sistem sosial untuk memelihara keberlangsungannya. Jika dikaitkan dengan teori struktural fungsional maka yang menjadi pihak Adaptation atau yang beradaptasinya adalah adat Tunggu Tubang dikalangan masyarakat Desa Gunung Agung selanjutnya diperoleh pencapaian tujuan atau goal attainment yang mana sistem Tunggu Tubang ini berlaku di dalam masyarakat dan berjalan dengan baik. Sehingga terjadi integrasi antara sistem Tunggu Tubang dengan masyarakat Suku Semende di Desa Gunung Agung. Penyatuan ini terlihat dengan dikenalnya masyarakat Suku Semendeini dengan ciri sistem Tunggu Tubang yang berlaku. Sehingga dari hal tersebut dilakukan pemeliharan menggunakan nilai-nilai yang dipatuhi oleh masyarakat dimana dalam teori Parson hal ini disebut dengan Latenci.

Maka dari itu dengan berlangsungnya sistem Tunggu Tubang yang sesuai dengan ketentuanketentuan yang berlaku maka akan terwujud kehidupan yang harmonis dan berkesinambungan. Hal ini sesuai dengan apa yang diungkapkan dalam teori Struktural Fungsional Talcott Parson bahwa masyarakat hanya perlu menaati aturan yang berlaku untuk terciptanya kesejahteraan dalam hidup. 


\section{KESIMPULAN}

Pembagian harta warisan dengan sistem Tunggu Tubang merupakan adat yang dimiliki oleh Suku Semende. Tunggu Tubang bukan hanya menyangkut mengenai pembagian harta warisan tetapi juga kepada sistem pernikahan dan sistem kekerabatan. Tunggu Tubang adalah anak perempuan yang terlahir pertama di dalam sebuah keluarga. Status sebagai Tunggu Tubang akan didapat setelah anak perempuan yang terlahir pertama tersebut telah menikah. Setelah menikah harta warisan yang telah diturunkan secara turuntemurun akan jatuh otomatis kepada anak tersebut, seiring beralihnya harta pusaka ini maka seorang Tunggu Tubang akan memiliki hak dan kewajiban.

Hak seorang Tunggu Tubang adalah mendapatkan rumah dan sebidang sawah namun harta pusaka ini hanya bisa dinikmati dan tidak bisa diperjualbelikan. Sedangkan, tugas dan tanggung jawab seorang Tunggu Tubang adalah menghimpun keluarga besar, mewakili keluarga besar, mengurus harta pusaka. Tunggu Tubang menjadi simbol sebuah keluarga di dalam suku Semende terutama di Desa Gunung Agung. Dalam menjalankan tugas dan kewajibannya Tunggu Tubang diawasi oleh Meraje (saudara laki-laki ibu). Peran dari laki-laki sangatlah penting, karena mereka inilah yang berperan mengawasi Tunggu Tubang. Mereka yang mempunyai status di atas harus ditaati perintahnya sepanjang untuk membangun dan memperbaiki apa yang berhubungan dengan Tunggu Tubang serta harta pusakanya. Mereka akan berada dibelakang, memberi teguran kalau ada kekurangan yang dilakukan Tunggu Tubang.

\section{REFERENSI}

Hadikusuma, H. (1991). Hukum Waris Adat. Bandung : Cipta Aditya Bhakti.

Haryanto, S. (2012). Spektrum teori sosial : dari kalsik hingga postmodern. Yogyakarta : Ar-Ruzz Media.

Saifudin, A.f. (2006) Antropologi Kontemporer. Suatu pengatar Kritis mengenai paradigma. Jakarta : kencana.

Hutapea, Y. Dan Tumarlan Tamrin. (2009). Eksistensi Tunggu Tubang sebagai Upaya Mempertahankan Sumber Daya Lahan Berkelanjutan. Jurnal Balai Pengkajian Teknologi Pertanian Sumatra Selatan, hlm $1-11$

Fakhri. (2001). Kedudukan Ahli Waris Terhadap Harta Tunggu Tubang Ditinjau Dari Hukum Adat dan Hukum Islam Pada Masyarakat Semendo di
Kabupaten Muara Enim. (Tesis). Pasca Sarjana. Universitas Sriwijaya, Palembang.. 